\title{
Executive Incentives and Maximization of the Value of Stakeholders - Regulating Effects Based on the Independent Director
}

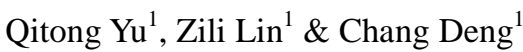 \\ ${ }^{1}$ Finance Department of International Bussiness School, Jinan University, Zhuhai, Guangdong Province, China \\ Correspondence: Zili Lin, Finance Department of International Business School, Jinan University, Qianshan \\ Road 206\#, Zhuhai City, Guangdong Province, Post No. 519070, China. E-mail: 874828107@qq.com
}

Received: July 27, 2018

Accepted: August 6, 2018

Online Published: August 10, 2018

doi:10.5539/ijef.v10n9p46

URL: https://doi.org/10.5539/ijef.v10n9p46

\begin{abstract}
Salary incentives mechanism is the main approach used by corporations to solve the agency issues between the management and shareholders. From the perspective of maintaining the maximum of stakeholders' value, this paper, using the data of A-share listed companies between 2012 and 2016, examines the effectiveness of cash compensation and equity-based incentives. Whether the relationship between the two can be regulated by the introduction of the independent director is further discussed. The empirical results indicate that cash compensation effectively increase the executive's concern about the interests of stakeholders, while equity-based incentives do just the opposite. In addition, regardless of the proportion of independent director, its regulating effects on the relationship between the two above is negative, causing an adverse effect on the executive's corporate governance in the light of maximization of the value of stakeholders.
\end{abstract}

Keywords: stakeholder, cash incentive, equity-based incentive, agency issue

\section{Introduction}

Under the modern enterprise system where the separation of ownership and management rights has applied, agency issue between executives and shareholders is the key point in corporate governance. According to the Principal-agent Theory, agency issues originate from the situation where shareholders as agents hire managers with professional skills and grant them the power of operating companies on the behalf of shareholders. Due to the discrepancies between interest of shareholders and that of executives, that is, the former seeks to maximize their own value while the latter expect more salary and leisure time. As a result, executives often use decision-making power to pursue their own interests without authorization and ignore the goal of maximizing enterprise value (Eisenhardt, 1989). When shareholders fail to supervise the behavior of executives, they may be motivated to take incentives to align executives with their own interest in hopes of solving agency problems.

Cash compensation incentives (including basic salary and performance bonus) and equity-based incentives are regraded as effective mechanism to moderate the conflict of interest between shareholders and executives (Jensen \& Murphy, 1990; Soyon, Xiao, Seoki, \& Song, 2013). Frydma et al. (2010) pointed out that remuneration incentives for executives of listed companies take positive governance effects on weakening principal-agent problems or promoting the convergence of executives' and shareholders' interests. The governance effects of equity-based incentives also have been proved and approved by most scholars. Studies have shown that, in western developed capital market, enterprises which grant proportional shares to CEO realize the convergence of executives' and shareholders' interests. Nevertheless, various factors, including the non-universality of equity-based incentives in listed companies, restrictions on the realization of shares and the immaturity of mechanism of the capital market, are likely to weaken the governance effect of equity-based incentives. Therefore, there is a need for further research on the effectiveness of executive incentives in China's capital markets.

Conventional wisdom has it that the aim of corporations' financial management is to realize the maximization of shareholders' wealth. And the purpose of implementing the executive compensation incentive plan is also to motivate executives to act in the interests of shareholders. With the proposal of stakeholder theory, scholars gradually came to realize that companies must maintain a long-term and stable relationship with stakeholders in order to survive and to achieve sustainable value-added benefits. (Patel, Manley, Jr, Ferrell, \& Pieper, 2016) Contrarily, companies tend to degenerate if it doesn't pay enough attention to the interest of all stakeholders or 
fails to set up a comprehensive set of common governance mechanisms for stakeholders. (Post, Preston, \& Sachs, 2002) Different from the past view that the corporate performance is only linked to the wealth of shareholders, a corporate is formed through the conclusion of contracts by stakeholders including shareholders (Freeman \& Evan, 1991), meaning its ownership is shared by all stakeholders. (Blair, 1994) Thus, the goal of operating such a corporate should be to create value and wealth for all stakeholders (Clarkson, 1995), while management also has fiduciary responsibility for stakeholders (Freeman, 1984). Besides, principal-agent relationship exists between all stakeholders, including shareholders, and the executives. The stakeholder theory emphasizes the responsibility for safeguarding the interests of all stakeholders, including shareholders in the course of company operations, incorporating the concept of meeting the needs of different stakeholder groups into the framework of corporate governance. The evolution of these modern corporate management concepts also requires us to re-examine the rationality of executive incentive content and evaluate the effectiveness of compensation incentive plan from the perspective of stakeholders.

At present, most of the literature examines the effectiveness of compensation incentives from the perspective of developed countries. However, due to factors such as the economic system, economic development level, and soundness of the legal system, the conclusions of developed countries may not necessarily apply to the emerging capital markets. The development of China's capital market is in its transitional stage, and the market mechanism has gradually matured. With the traditional "salary + bonus" incentive model still occupying a large market, whether the introduction of equity incentive model can encourage enterprises to obtain greater economic and non-economic benefits, whether the original intention of the compensation incentive plan design can be effectively implemented, and whether the introduction of external independent directors can positively regulate the relationship between executive incentives and stakeholder maximization are still questioning. Based on the above thinking, this paper uses the A-shares listed on the Shanghai Stock Exchange and the Shenzhen Stock Exchange as examples to study the correlation between executive compensation plans, independent directors and the goal of maximizing the value of stakeholders in terms of monetary compensation and equity incentives. This paper also investigates whether the implementation of executive compensation plans can effectively alleviate the agency problems caused by information asymmetry and realize the goal of maximizing the value of corporate stakeholders. Studying these topics can not only provide theoretical guidance for improving the corporate governance mechanism of listed companies in China, but also provide reference for future practice in other emerging market countries.

\section{Literature Review}

The goal of corporate social responsibility is to maximize the value of shareholders and other stakeholders (European Commission, 2011). Therefore, the protection of stakeholders' rights and interests is closely related to corporate social responsibility performance (Jamali, Safieddine, \& Rabbath, 2010). The fulfillment of social responsibilities can reflect that the company conducts corporate governance with the goal of maximizing the value of stakeholders, while the non-fulfilment of social responsibilities or the lack of socially responsible activities are deemed to be "adventurous" (Mcguire, Dow, \& Argheyd, 2003). Senior executives are typical risk averters. When higher monetary compensation establishes exclusive human capital for senior executives, it also means that executives are more closely linked to companies(Gray \& Jr., 1997). Therefore, they are reluctant to default on social responsibility or carry out activities lack of social responsibility at the price of corporate reputation. High monetary rewards can also enhance the job satisfaction of senior executives and prove their existence value. The greater the incentive intensity of monetary compensation, the more they can make up for the personal costs that executive pay for the corporate change. As a professional manager, the vertical pay gap can meet the psychological needs of its status and authority. In addition, they also hope to prove their strength by ensuring efficient operation inside the organization, improving the company's operating performance, and coordinating the interests of all parties, thereby gaining reputation and support from stakeholders (Ferris, Perrewé, Ranft, Zinko, Stoner, Brouer, \& Lairda, 2007). Therefore, corporate executives will pay more attention to the interests of internal and external stakeholders, and strive to satisfy their value needs through social responsibility activities, so as to maintain a long-term and stable relationship with stakeholders and gain a good reputation or other potential benefits (Soyon, Xiao, Seoki, \& Song, 2013). According to the above analysis, hypothesis 1 is proposed.

Hypothesis 1: as monetary compensation rises, executives tend to conduct corporate governance from the perspective of maximizing the value of stakeholders.

Denis, Hanouna, and Sarin (2006) believe that equity-based incentives will lead senior executives to take greater risks. On the one hand, in order to maximize the company's stock price, executives may engage in fraudulent criminal activities such as manipulating the market's perception of the value of the shares; on the other hand, the 
implementation of equity-based incentive plan allows executives to receive appropriate incentives when corporate performance improves. When the performance declines, executives can choose not to exercise the right to avoid penalties associated with falling share prices. It is this asymmetry of returns that drives senior executives to be motivated to take greater risks because corporate social responsible activities can be subject to managerial discretion, which in turn can be influenced by executive incentives mechanism (Mcguire, Dow, \& Argheyd, 2003). Therefore, this kind of risk incentive mechanism nested in the equity incentive plan will encourage companies to engage in more activities lack of social responsibility. Although these adventurous activities will do harm to the interests of stakeholders, executives tend to underestimate the negative impact of these activities on the company and believe that they can respond well to these negative results (Tang, Qian, Chen, \& Shen, 2015). Based on that, hypothesis 2 is proposed.

Hypothesis 2: the implementation of the equity-based incentive plan is not conducive to the executive management of the company from the perspective of maximizing the value of stakeholders.

Denis et al. (2006) think that the relationship between equity incentives and excessive risk-taking is also related to the corporate governance structure, such as the proportion of external independent directors. One of the main duties of independent directors is to supervise and control the behavior of senior executives. At the same time, as a link between the company and the outside (Gabrielsson \& Huse, 2005), independent directors must also consider the overall interest demands of shareholders (Ibrahim \& Angelidis, 1995). But in China, the company law stipulates that the president can attend the board of directors, while the independent director candidates are nominated by the board members, which means that the nominations and appointments of independent directors are influenced by executives, so executives tend to nominate independent directors who have social connections with them (Zhou, Fan, An, \& Zhong, 2017), meaning that independent directors may not be truly independent. Such kind of relationship makes independent directors unable to effectively perform supervisory functions, and often uses more equity-based compensation as a substitute for direct supervision (Holmstrom \& Milgrom, 1994; Alonso, Aperte, \& Sanz, 2017). On the one hand, more shareholding compensation means that executives are less willing to avoid risk. On the other hand, a smaller degree of supervision will reduce the pressure on business performance, and the penalty for fraudulent activities is relatively small. Then executives are also able to retain their positions (Zhou, Zhang, Yang, Su, \& An, 2018). In other words, when there is a relatively large proportion of independent directors who are unwilling to perform supervisory duties on the board of directors, it is equivalent to providing executives with implicit job guarantees, driving executives to be motivated to engage in fraud and other social deficiencies or not to perform social responsibilities, thus harming the interests of stakeholders. Even if there are independent directors who are willing to perform supervisory functions, when executives know that independent directors ask for internal information for the purpose of monitoring or even penalizing, they are often reluctant to disclose the company's operations to independent directors or even deliberately invest in special projects to intensify the information asymmetry between the two, in order to achieve the purpose of preventing independent directors from imposing discipline. In the light of this theory, hypothesis 3 is proposed.

Hypothesis 3: independent directors play a negatively regulatory role in the relationship between compensation incentives and maximization of stakeholders' value.

\section{Variables and Model}

\subsection{Variables}

The stakeholder's interest is taken as the explanatory variable. The goal of corporate social responsibility is to maximize the value of shareholders and other stakeholders (European Commission, 2011). Therefore, the stakeholder's interest is closely related to the performance of corporate social responsibility (Jamali, Safieddine, \& Rabbath, 2010). The rating of social responsibility report disclosure are used as proxy variable for the explanatory variable. Besides, explanatory variables include monetary compensation and equity-based compensation. The top three remuneration packages of senior executives are selected for monetary compensation, including basic salary and bonuses; because the Chinese listed companies are less subject to the implementation of equity-based incentive plans or relevant information on their disclosures of the plan is insufficient, this article uses the proportion of senior management shares disclosed in the annual report as the proxy variable of the equity-based incentive. In order to control the research bias brought about by other factors, this paper selects the following control variables: company size, asset-liability ratio, shareholding balance, nature of property rights, company growth rate, institutional ownership, industry, and year.

\subsection{Model}

In order to study the effectiveness of executive compensation incentives from the perspective of maximization of 
the value of stakeholders, this paper designs the following models for hypothesis testing:

$$
\begin{aligned}
& \text { Score }_{i, t}=\beta_{0}+\beta_{1} \text { Salary }_{i, t}+\beta_{2} \text { Hold }_{i, t}+\beta_{3} \text { Size }_{i, t}+\beta_{4} \text { Lev }_{i, t}+\beta_{5} \text { Balance }_{i, t}+\beta_{6} \text { State }_{i, t}++\beta_{7} \text { Growth }_{i, t} \\
& +\beta_{8} \text { Inst }_{i, t}+\sum \text { Indus }+\sum \text { Year }+\varepsilon_{i, t} \\
& \text { Score }_{i, t}=\beta_{0}+\beta_{1} \text { Salary }_{i, t}+\beta_{2} \text { Hold }_{i, t}+\beta_{3} \text { Salaryindep }_{i, t}+\beta_{4} \text { Holdindep }_{i, t}+\beta_{5} \text { Indep }_{i, t}+\beta_{6} \text { Size }_{i, t}+ \\
& \beta_{7} \text { Lev }_{i, t}+\beta_{8} \text { Balance }_{i, t}+\beta_{9} \text { State }_{i, t}++\beta_{10} \text { Growth }_{i, t}+\beta_{11} \text { Inst }_{i, t}+\sum \text { Indus }+\sum \text { Year }+\varepsilon_{i, t}
\end{aligned}
$$

\section{Result}

\subsection{Descriptive Statistics}

The descriptive results of the variables are shown in Table . From Table 1, it can be seen that, among companies disclosing the report, the report rating score is 39.94 . In the aspect of executive compensation incentives, the average compensation incentives of the top three executives of each company is 2.129 million yuan, and the average ratio of senior management shareholders is $1.12 \%$. The small number of shares held is a common phenomenon.

Table 1. Descriptive statistics

\begin{tabular}{cccccc}
\hline Variable & Obs & Mean & Std.Dev. & Min & Max \\
\hline Score & 2369 & 39.94 & 12.33 & 15.12 & 87.95 \\
Salary & 6744 & 212.9 & 223.8 & 0.84 & 3630 \\
Hold & 6744 & 1.12 & 5.62 & 0 & 80.96 \\
Size & 6744 & $1.54 \mathrm{e}+06$ & $9.78 \mathrm{e}+06$ & 0 & $2.88 \mathrm{e}+08$ \\
Lev & 6744 & 0.52 & 0.80 & 0.02 & 63.97 \\
Balance & 6744 & 1.55 & 0.55 & 1 & 4.99 \\
State & 6744 & 0.61 & 0.49 & -0.93 & 1 \\
Growth & 6744 & 0.52 & 8.42 & 0 & 376.4 \\
Inst & 6744 & 6.55 & 10.40 & 18.18 & 87.89 \\
Indep & 6744 & 37.23 & 5.615 & & 80 \\
\hline
\end{tabular}

\subsection{Empirical Results}

Table 2 shows the impact of the executive monetary compensation and equity-based incentives on the disclosure of corporate social responsibility reports. In terms of monetary compensation, both the traditional multiple regression method and the two-stage Heckman method passed the $1 \%$ significance test, indicating that monetary compensation incentives are significant and robust for senior executives to focus on stakeholder protection even though the existence of sample selection error. By the time when the monetary compensation rises by $1 \%$, the scores of corporate social responsibility report disclosures increase, indicating that high monetary compensation can enhance the job satisfaction of senior executives as well as link their returns to the reputation of the company and prevent them from engaging in activities that lack social responsibility or standing aside from social responsibility activities. When it comes to the equity-based incentives, each regression result shows that equity incentives are negatively related to the disclosure of social responsibility reports, and regression results (3), (4) are all significant at a level of $10 \%$, meaning that the asymmetry of equity-based compensation does lead executives to have excessive risk-taking motivation to engage in activities such as fraud, market manipulation and other activities lack of social responsibility, by which the interests of stakeholders may be damaged. So equity-based incentives are not conducive for executives to achieve corporate governance from the perspective of maximizing the value of stakeholders, which supports hypothesis 1 and hypothesis 2 . 
Table 2. Regression analysis on the impact of executive incentive compensation and stakeholder value maximization

\begin{tabular}{|c|c|c|c|c|c|c|c|c|}
\hline Variables & $\begin{array}{c}\text { OLS } \\
(1) \\
\end{array}$ & $\begin{array}{c}\text { Heckman } \\
\text { (2) }\end{array}$ & $\begin{array}{c}\text { OLS } \\
(3) \\
\end{array}$ & $\begin{array}{c}\text { Heckman } \\
(4)\end{array}$ & $\begin{array}{c}\text { OLS } \\
(5) \\
\end{array}$ & $\begin{array}{c}\text { Heckman } \\
(6)\end{array}$ & $\begin{array}{c}\text { OLS } \\
(7) \\
\end{array}$ & $\begin{array}{c}\text { Heckman } \\
(8)\end{array}$ \\
\hline \multirow[t]{2}{*}{ Salary } & $0.01 * * *$ & $0.01 * * *$ & $0.01 * * *$ & $0.01 * * *$ & $0.03 * * *$ & $0.03 * * *$ & $0.01 * * *$ & $0.01 * * *$ \\
\hline & $(0.001)$ & $(0.001)$ & $(0.001)$ & $(0.001)$ & $(0.01)$ & $(0.01)$ & $(0.001)$ & $(0.001)$ \\
\hline \multirow[t]{2}{*}{ Hold } & -0.01 & -0.02 & $-0.02 *$ & $-0.02 *$ & -0.03 & -0.02 & $-0.54 *$ & $-0.51 *$ \\
\hline & $(0.05)$ & $(0.06)$ & $(0.01)$ & $(0.01)$ & $(0.05)$ & $(0.05)$ & $(0.29)$ & $(0.31)$ \\
\hline \multirow[t]{2}{*}{ Salaryindep } & & & & & $-0.0004 * * *$ & $-0.0004 * * *$ & & \\
\hline & & & & & $(0.0002)$ & $(0.0002)$ & & \\
\hline \multirow[t]{2}{*}{ Holdindep } & & & & & & & $-0.01 *$ & $-0.01 *$ \\
\hline & & & & & & & $(0.01)$ & $(0.01)$ \\
\hline \multirow[t]{2}{*}{ indep } & & & & & $0.13^{* *}$ & $0.11 *$ & 0.01 & -0.01 \\
\hline & & & & & $(0.06)$ & $(0.06)$ & $(0.04)$ & $(0.04)$ \\
\hline \multirow[t]{2}{*}{ Size } & $1.94 \mathrm{e}-07 * * *$ & $2.32 \mathrm{e}-07 * * *$ & $1.75 \mathrm{e}-07 * * *$ & $2.11 \mathrm{e}-07 * * *$ & $1.75 \mathrm{e}-07 * * *$ & $2.12 \mathrm{e}-07 * * *$ & $1.75 \mathrm{e}-07 * * *$ & $2.12 \mathrm{e}-07 * * *$ \\
\hline & $(1.44 \mathrm{e}-08)$ & (1.66e-08) & $(1.44 \mathrm{e}-08)$ & $(1.67 \mathrm{e}-08)$ & $(1.45 \mathrm{e}-08)$ & $(1.67 \mathrm{e}-08)$ & $(1.45 \mathrm{e}-08)$ & $(1.67 e-08)$ \\
\hline \multirow[t]{2}{*}{ Lev } & $3.179 * * *$ & $3.14 * *$ & $5.54 * * *$ & $5.69 * * *$ & $5.56 * * *$ & $5.70 * * *$ & $5.65 * * *$ & $5.78 * * *$ \\
\hline & $(1.21)$ & $(1.23)$ & $(1.27)$ & $(1.29)$ & $(1.27)$ & $(1.28)$ & $(1.27)$ & $(1.29)$ \\
\hline \multirow[t]{2}{*}{ Balance } & $1.40 * * *$ & $1.56^{* * * *}$ & $0.80^{*}$ & $0.89 * *$ & $0.77 *$ & $0.86^{*}$ & $0.76^{*}$ & $0.85^{*}$ \\
\hline & $(0.46)$ & $(0.46)$ & $(0.45)$ & $(0.45)$ & $(0.44)$ & $(0.45)$ & $(0.45)$ & $(0.45)$ \\
\hline \multirow[t]{2}{*}{ State } & $5.64 * * *$ & $5.48 * * *$ & $4.53 * * *$ & $4.36^{* * * *}$ & $4.45^{* * * *}$ & $4.28 * * *$ & $4.57 * * *$ & $4.41 * * *$ \\
\hline & $(0.56)$ & $(0.57)$ & $(0.56)$ & $(0.57)$ & $(0.56)$ & $(0.57)$ & $(0.57)$ & $(0.57)$ \\
\hline \multirow[t]{2}{*}{ Growth } & -0.44 & -0.51 & -0.25 & -0.33 & -0.26 & -0.33 & -0.24 & -0.32 \\
\hline & $(0.62)$ & $(0.62)$ & $(0.60)$ & $(0.59)$ & $(0.60)$ & $(0.59)$ & $(0.60)$ & $(0.59)$ \\
\hline \multirow[t]{2}{*}{ Inst } & $0.05 * *$ & $0.05 * *$ & $0.05 * * *$ & $0.05 * * *$ & $0.05 * * *$ & $0.05 * * *$ & $0.05 * * *$ & $0.06 * * *$ \\
\hline & $(0.02)$ & $(0.02)$ & $(0.02)$ & $(0.02)$ & $(0.02)$ & $(0.02)$ & $(0.02)$ & $(0.02)$ \\
\hline \multirow[t]{2}{*}{ Cons } & $28.50 * * *$ & $28.61 * * *$ & $30.13 * * *$ & $30.35 * * *$ & $25.21 * * *$ & $26.24 * * *$ & $29.56 * * *$ & $30.74 * * *$ \\
\hline & (1.08) & (1.10) & $(3.83)$ & $(4.29)$ & $(4.47)$ & $(4.90)$ & (4.14) & $(4.60)$ \\
\hline Indus & No & No & Yes & Yes & Yes & Yes & Yes & Yes \\
\hline Year & No & No & Yes & Yes & Yes & Yes & Yes & Yes \\
\hline Obs & 2,369 & 6,744 & 2,369 & 6,579 & 2,369 & 6,579 & 2,369 & 6,579 \\
\hline Adj.R-sq & 0.17 & & 0.23 & & 0.23 & & 0.23 & \\
\hline $\mathrm{F}$ & 59.61 & & 26.01 & & 24.58 & & 24.38 & \\
\hline lambda & & $-1.95^{*}$ & & $-2.16^{* *}$ & & $-2.13 * *$ & & $-2.14 * *$ \\
\hline Wald chi2 & & 482.16 & & 731.64 & & 741.75 & & 734.74 \\
\hline
\end{tabular}

$* * *, * *$, and $*$ denote statistical significance at $1 \%, 5 \%$, and $10 \%$, respectively. The significance of the test results are based on the two-tailed tests. OLS or Heckman two-stage estimators are used in the regression.

The regression results (5),(6),(7) and (8) reveals the regulating effect of the independent director system on compensation incentives and maximization of the value of stakeholders. In regression results (5) and (6), Salaryindep, the interaction item of the monetary compensation and independent directors, passes the test with a significance level of $1 \%$. When Salaryindep increases by $1 \%$, the score of social responsibility report disclosure decreases by $0.04 \%$. In the regression results (7) and (8), Holdindep, the interaction of equity remuneration and independent directors, passes the test with a significance level of $10 \%$. When Holdindep rises by $1 \%$, the score of social responsibility report disclosure decreases by $0.1 \%$. Independent directors play a negative role in the relationship between the monetary compensation and the maximization of stakeholders' value, or between the 
equity-based compensation and the maximization of stakeholders' value. This shows that independent directors of listed companies in China cannot effectively play a supervisory role, prompting senior executives to perform corporate governance in accordance with the goal of maximizing the interest of stakeholders, which supports hypothesis 3.

\section{Conclusion}

This study provides empirical evidence on the relationship between executive incentive compensation mechanism and stakeholder value maximization in China, and the moderation effect of independent director on the above relationship by using the OLS and two-stage Heckman method which can solving the sample selection error. We find that managers with high level of monetary income are more likely to engage in social responsible activities and thus positively associated with stakeholder value maximization, while equity-based compensation embedded with risk-taking incentives cause managers to involve in more of the socially irresponsible activities in order to maximize company's stock price and thereby ignore the importance of stakeholders and even damage the interest of stakeholders. We also find that independent directors in the board exert a negative moderating effect on the relationship between executive incentive and stakeholder wealth maximization because independent directors in Chinese firms are closely tied with top managers. Our study explores the impact of executive compensation and independent director on corporate governance, which may contribute to a better understanding of the principal-agent problems in Chinese firms.

\section{Acknowledgments}

This work was supported by Student's Platform for Innovation and Entrepreneurship Training Program No. 201810559085 \& 201810559093.

\section{References}

Alonso, P. D. A., Aperte, L. A., \& Sanz, J. A. R. (2017). Independent versus non-independent outside directors in European companies: Who has a say on CEO compensation? Business Research Quarterly, 20(2), 79-95. https://doi.org/10.1016/j.brq.2017.02.001

Armstrong, C. S., Core, J. E., \& Guay, W. R. (2012). Do independent directors cause improvements in firm transparency? Journal of Financial Economics, 113(3), 383-403. https://doi.org/10.1016/j.jfineco.2014.05.009

Boschen, J. F., Duru, A., Gordon, L. A., \& Smith, K. J. (2003). Accounting and stock price performance in dynamic CEO compensation arrangements. Accounting Review, 78(1), 143-168. https://doi.org/10.2308/accr.2003.78.1.143

Bouslah, K., Liñares-Zegarra, J., M'Zali, B., \& Scholtens, B. (2017). CEO risk-taking incentives and socially irresponsible activities. British Accounting Review, 50, 76-92. https://doi.org/10.1016/j.bar.2017.05.004

Burns, N., Mc Tier, B., \& Minnick, K. (2015). Equity-incentive Compensation and Payout Policy in Europe. Journal of Corporate Finance, 30(3), 85-97. https://doi.org/10.1016/j.jcorpfin.2014.10.019

Clarkson, M. B. E. (1995). A Stakeholder Framework for Analyzing and Evaluating Corporate Social $\begin{array}{llll}\text { Performance. Academy of } & \text { Management }\end{array}$ https://doi.org/10.5465/amr.1995.9503271994

Denis, D. J., Hanouna, P., \& Sarin, A. (2006). Is there a dark side to incentive compensation? Journal of Corporate Finance, 12(3), 467-488. https://doi.org/10.1016/j.jcorpfin.2005.08.006

Edlin, A. S., \& Stiglitz, J. E. (1995). Discouraging Rivals: Managerial Rent-Seeking and Economic Inefficiencies. American Economic Review, 85(5), 1301-1312.

Eisenhardt, K. M. (1989). Agency theory: An assessment and review. The Academy of Management Review, 14(1), 57-74. https://doi.org/10.5465/amr.1989.4279003

European Commission. (2011). A renewed EU strategy 2011-14 for corporate social responsibility (COM/2011/0681, 25/10/2011). Office for Official Publications of the European Communities, Luxembourg.

Evans, A. (2008). Portfolio Manager Ownership and Mutual Fund Performance. Financial Management, 37(3), 513-534. https://doi.org/10.1111/j.1755-053X.2008.00023.x

Firth, M., Fung, P. M. Y., \& Rui, O. M. (2006). Corporate performance and CEO compensation in China. Journal of Corporate Finance, 12(4), 693-714. https://doi.org/10.1016/j.jcorpfin.2005.03.002 
Freeman, R. E. (1984). Strategic management:a stakeholder approach. Boston: Pitman.

Freeman, R. E., \& Evan, W. M. (1991). Corporate Governance: a Stakeholder Interpretation. Journal of Behavioral Economics, 19(4), 337-359. https://doi.org/10.1016/0090-5720(90)90022-Y

Frydman, C., \& Saks, R. (2010). Executive Compensation: A New View from a Long-term Perspective, 1936-2005. Review of Financial Studies, 23(5), 2099-2138. https://doi.org/10.1093/rfs/hhp120

Gabrielsson, J., \& Huse, M. (2005). Outside' directors in SME boards: A call for theoretical reflections. Corporate Board Roles Duties \& Composition, 1. https://doi.org/10.22495/cbv1i1art3

García-Sánchez, I. M. (2015). The ethical commitment of independent directors in different contexts of investor protection. Business Research Quarterly, 18(2), 81-94. https://doi.org/10.1016/j.brq.2014.07.001

Gray, S. R., \& Jr, A. A. C. (1997). The role of risk in executive compensation. Journal of Management, 23(4), 517-540. https://doi.org/10.1177/014920639702300402

Gunasekargea, A., \& Wilkinson, M. (2002). CEO compensation and firm performance: A New Zealand investigation. International Journal of Business Studies, 10(2), 45-59.

Holmstrom, B., \& Milgrom, P. (1991). Multitask Principal-Agent Analyses: Incentive Contracts, Asset Ownership, and Job Design. Journal of Law Economics \& Organization, 7(Special Issue), 24-52. https://doi.org/10.1093/jleo/7.special_issue.24

Holmstrom, B., \& Milgrom, P. (1994). The Firm as an Incentive System. American Economic Review, 84(4), 972-991.

Ibrahim, N. A., \& Angelidis, J. P. (1995). The corporate social responsiveness orientation of board members: Are there differences between inside and outside directors? Journal of Business Ethics, 14(5), 405-410. https://doi.org/10.1007/BF00872102

Jamali, D., Safieddine, A. M., \& Rabbath, M. (2010). Corporate Governance and Corporate Social Responsibility Synergies and Interrelationships. Corporate Governance An International Review, 16(5), 443-459. https://doi.org/10.1111/j.1467-8683.2008.00702.x

Jensen, M. C., \& Murphy, K. J. (1990). Performance Compensation and Top Management Incentives. Journal of Political Economy, 98(2), 225-264. https://doi.org/10.1086/261677

Jensen, M. C., \& Murphy, K. J. (1990). Performance Pay and Top-Management Incentives. Journal of Political Economy, 98(2), 225-264. https://doi.org/10.1086/261677

Margaret, M. B. (1994). Ownership and Control: Rethinking Corporate Governance for the Twenty-First Century. Brookings Institution Press.

Mcguire, J., Dow, S., \& Argheyd, K. (2003). CEO Incentives and Corporate Social Performance. Journal of Business Ethics, 45(4), 341-359. https://doi.org/10.1023/A:1024119604363

Meng, Y., Clements, M. P., \& Padgett, C. (2017). Independent Directors, Information Costs and Foreign Ownership in Chinese Companies. Journal of International Financial Markets Institutions \& Money, 53, 139-157. https://doi.org/10.1016/j.intfin.2017.09.016

Patel, V. K., Manley, S. C., Jr, J. F. H., Ferrell, O. C., \& Pieper, T. M. (2016). Is stakeholder orientation relevant for European firms? European Management Journal, 34(6), 650-660. https://doi.org/10.1016/j.emj.2016.07.001

Post, J., Preston, L., \& Sachs, S. (2002). Managing the extended enterprise: The new stakeholder view. California Management Review, 45(1), 6-28. https://doi.org/10.2307/41166151

Soyon, P., Xiao, Q., Seoki, L., \& Song, H. Y. (2013). Does managerial ownership affect different corporate social responsibility dimensions? An empirical examination of U.S. publicly traded hospitality firms. International Journal of Hospitality Management, 34(6), 423-433.

Tang, Y., Qian, C., Chen, G., \& Shen, R. (2015). How CEO hubris affects corporate social (ir)responsibility. Strategic Management Journal, 36(9), 1338-1357. https://doi.org/10.1002/smj.2286

Torea, N. G., Feijoo, B. F., \& González, M. D. L. C. (2016). Board of director's effectiveness and the stakeholder perspective of corporate governance: Do effective boards promote the interests of shareholders and stakeholders? Business Research Quarterly, 19(4), 246-260. https://doi.org/10.1016/j.brq.2016.06.001

Zhou, F., Fan, Y., An, Y., \& Zhong, L. (2017). Independent directors, non-controlling directors, and executive 
pay-for-performance sensitivity: Evidence from Chinese non-state owned enterprises. Pacific-Basin Finance Journal, 43, 55-71. https://doi.org/10.1016/j.pacfin.2017.02.003

Zhou, F., Zhang, Z., Yang, J., Su, Y., \& An, Y. (2018). Delisting pressure, executive compensation, and corporate fraud: Evidence from China. Pacific-Basin Finance Journal, 48, 17-34. https://doi.org/10.1016/j.pacfin.2018.01.003

\section{Copyrights}

Copyright for this article is retained by the author(s), with first publication rights granted to the journal.

This is an open-access article distributed under the terms and conditions of the Creative Commons Attribution license (http://creativecommons.org/licenses/by/4.0/). 